\title{
OPTIMALISASI PERAN BANK SYARIAH DALAM MENGEMBANGKAN INDUSTRI HALAL DI INDONESIA MELALUI SINERGI KELEMBAGAAN
}

\author{
Sri Apriyanti Husain \\ IAIN Sultan Amai Gorontalo \\ e-mail: sriapriyantihusain@iaingorontalo.ac.id
}

\begin{abstract}
The halal industry in Indonesia is expected to grow faster than in other countries. However, this can be achieved if it can optimize the financial sectors, one of which is Islamic banks. Islamic banks have an essential role in developing the halal industry. This is also, of course, inseparable from Indonesia's demographic bonus as a country with the largest Muslim population in the world. The Researcher used qualitative descriptive research as a research method. The Researcher conducted an exploratory study on optimizing the role of Islamic banks in developing the halal industry in Indonesia. Islamic banks must optimize their function through institutional synergy. Institutional synergies that Islamic banks must carry out to maximize their role in developing the halal industry in Indonesia are: First, institutional synergy with the government. The forms of institutional synergy carried out by the government Islamic banks are (1) identification and mapping of areas for the halal tourism sector; (2) support for strengthening regulations, standardization, and supervision processes for halal products. Second, the institutional synergy of Islamic banks with halal industry players. The form of institutional synergy with Islamic banks with the halal industry can be done by (1) identification and development of industrial models; (2) support for strengthening and providing outlets and market access; (3) provision of financing funds; (4) education and assistance. And the third is the synergy of Islamic banks with educational institutions by including halal industry awareness in educational institutions.
\end{abstract}

Keywords: optimization; the role of Islamic banks; halal industry; institutional synergy

\section{Pendahuluan}

Industri halal saat ini semakin mendapatkan perhatian khusus dan sudah menjadi tren di kalangan masyarakat dunia. Tren masyarakat dunia tentang industri halal ini ditandai dengan laporan yang dikeluarkan oleh Global Islamic Economy Report periode 2018-2019 yang memperkirakan pengeluaran muslim secara global pada sektor lifestyle pada tahun 2017 mencapai 2,1 triliun dollar Amerika, sementara sektor islamic finance total aset mencapai 2,4 triliun dollar Amerika, halal food mencapai 1,3 triliun dollar Amerika, fashion mencapai 270 miliar dollar Amerika, kemudian media and recreation yang mencapai 209 miliar dollar Amerika, selanjutnya halal travel yang mencapai 177 miliar dollar Amerika, serta belanja pharmachy and cosmetics yang mencapai masing-masing mencapai 87 miliar dollar Amerika dan 61 miliar dollar Amerika.

Data di atas menunjukkan bahwa industri halal memiliki potensi yang besar untuk dikembangakan, baik itu di kalangan mayoritas muslim dan non muslim. Global Islamic Economy Report periode 2018-2019 mencatat negara-negara mayoritas non muslim, seperti 
Brazil, Australia, China, Prancis, Thailand, Singapura dan Jerman kini masuk dalam 10 besar di beberapa sektor industri halal. Negara-negara di Asia Tenggara terlebih Indonesia yang memiliki potensi lebih dalam mengembangkan industri halal. Dengan bonus demografi yang dimiliki Indonesia sebagai negara dengan jumlah populasi muslim terbesar di dunia tentu hal ini dapat mempercepat pertumbuhan dan pengembangan industri halal. Salah satu organisasi dunia, yakni The Pew Forum on Religion and Public Life telah merilis jumlah penganut agama Islam di Indonesia mencapai 209,1 juta jiwa atau $87,2 \%$ dari total jumlah penduduk. Jumlah tersebut merupakan $13,1 \%$ dari jumlah seluruh umat Islam di dunia. Negara berpenduduk muslim kedua terbesar yakni India. Di negara ini, penganut agama Islam mencapai 176,4 juta jiwa atau $14,4 \%$.

Global Islamic Economy Report periode 2018-2019 mencatatat bahwa Indonesia masuk pada Top 15 Countries GIE Indicator Score dan berada di peringkat ke-10 dengan skor 45 setelah di tahun sebelumnya menempati peringkat ke-11. Meski posisi ini lebih bagus dari Brunei, Sudan, Iran, Bangladesh dan Turki, tapi posisi ini masih jauh tertinggal dari Malaysia, UEA dan Bahrain yang menempati posisi 1, 2 dan 3. Indonesia dalam GIE masuk dalam beberapa sektor, yakni islamic finance yang menempati posisi ke-10, halal travel yang menempati posisi ke-4 dan modest fashion yang menempati posisi ke-2.

Sektor keuangan Islam mendapatkan perhatian cukup penting dari pemerintah Indonesia. Pemerintah Indonesia berupaya untuk terus meningkatkan sektor keuangan Islam karena sektor berperan dalam perekonomian negara. Pertumbuhan sektor keuangan Islam di Indonesia terbilang cukup baik. Otoritas Jasa Keuangan telah mencatat total aset syariah pada tahun 2018 sebesar 25\%, yakni 1.118 triliun rupiah. Bank syariah memberikan kontribusi terbesar dalam pertumbuhan aset syariah di Indonesia. Ketua Dewan Komisioner OJK menyatakan bahwa kinerja bank syariah tercermin dari posisi aset perbankan syariah yang tercatat secara tahunan masih tumbuh sebesar 20,65\% menjadi 429,36 triliun rupiah. Posisi likuiditas yang masih bergerak ke arah positif. Hal ini bisa dilihat dari posisi DPK yang naik 16,1\% menjadi 339,05 triliun rupiah. ${ }^{1}$ Bank Syariah yang tumbuh secara positif diharapkan mampu mengoptimalkan perannya dalam mengambangkan industri halal di Indonesia karena industri halal tidak hanya sekedar tren saja, tapi hal ini juga berkaitan dengan diri kita, berkaitan dengan kebaikan di dunia dan akhirat, terlebih konsep kehalalan ini sudah jelas diatur dalam agama Islam. ${ }^{2}$

Peran yang dilakukan bank syariah sejauh ini hanya sebatas dalam penyaluran pembiayaan kepada UMKM yang memiliki omset kecil maupun omset besar. Dalam penyaluran pembiayaan yang dilakukan bank syariah sejauh ini belum berjalan optimal. ${ }^{3}$ Salah satu penelitian menyatakan bahwa kinerja bank syariah belum mampu mendorong kinerja sektor riil secara optimal. ${ }^{4}$ Untuk mengoptimalkan perannya, bank syariah harus bersinergi dengan stakeholders yang berkepentingan dan memiliki visi yang sama dalam mengembangkan industri halal.

\footnotetext{
${ }^{1}$ OJK, “Aset Bank Syariah Tumbuh 20,65\% Per Februari”, Kontan, Februari 2018.

${ }^{2}$ Al-Quran, 2: 168-169, 172-173, 219; 5: 1, 3, 4-5, 87-88, 90-91; 23: 64; 7: 157; 16: 66, 68-69; 6: 121.

3 Kornitasari, dkk., "Desain Kelembagaan dalam Membangun Kepercayaan Diri Perbankan Syariah: Peran, Fungsi dan Potensi Kinerja Sektor Riil di Indonesia”, Kumpulan Hasil Riset Terbaik FREKS, 2015.

${ }^{4}$ Fasih, "Inclusiv Growth in India through Islamic Banking", Procedia Social-Behavioral Science, Volume 37, Nomor 1 (2012), 98.
} 


\section{Metodologi Penelitian}

Penelitian ini merupakan penelitian deskriptif kualitatif dengan melakukan kajian eksploratif terhadap optimalisasi peran bank syariah dalam mengembangkan industri halal di Indonesia. Peneliti menggunakan hasil wawancara sebagai data primer, kemudian data sekunder yang berasal dari jurnal, artikel, kata-kata tertulis, dokumentasi atau hal lain yang mendukung dan berkaitan dengan hal yang diteliti.

Untuk mendukung penelitian, maka digunakan tiga teknik pengumpulan data. Pertama, diskusi maupun wawancara dengan para ahli yang memiliki kaitan dengan isu penelitian baik yang berasal dari akademisi yang memiliki ilmu dan concern terhadap perkembangan ekonomi dan keuangan syariah serta industri halal, maupun dari unsur praktisi, yakni pegawai bank syariah yang dalam hal ini menangani tentang pembiayaan yang ada di bank syariah, selanjutnya pelaku industri halal, LPPOM MUI, dan unsur pemerintah. Kedua, studi pustaka dengan mengumpulkan data dari buku yang ada kaitannya dengan isu penelitian, jurnal ilmiah, artikel, maupun laporan yang ada kaitannya dengan bank syariah, pengembangan industri halal dan lainnya yang ada kaitannya dengan isu penelitian. Ketiga, dengan cara intuitif-subjektif, yaitu teknik pengumpulan data yang melibatkan pendapat penulis terkait isu penelitian. Dalam hal menganalisis data, peneliti mengadopsi analisis data Miles dan Hubermen di mana kegiatan yang berkenaan dengan analisis data meliputi reduksi data, penyajian data, penarikan kesimpulan dan verifikasi. ${ }^{5}$

\section{Peluang dan Tantangan dalam Pengembangan Industri Halal}

Industri halal yang sudah menjadi tren di kalangan masyarakat dunia bahkan bukan hanya masyarakat dengan mayoritas muslim saja, namun negara dengan muslim minoritas pun sudah mulai mengembangkan industri halal. Indonesia sebagai negara dengan mayoritas penduduk muslim terbesar tentunya memiliki peluang yang besar dibandingkan dengan negara lainnya. Apalagi Indonesia terkenal dengan melimpahnya sumber daya alam, tentu hal ini akan menjadi peluang Indonesia menjadi negara produsen terbesar dalam menghasilkan produk-produk halal. Dengan bonus demografi yang dimiliki Indonesia tentu masyarakat diharapkan memiliki kepahaman tentang ilmu agama dan kaitannya dengan kehalalan.

Secara legalitas, Indonesia sebenarnya telah memiliki kekuatan hukum, yakni lahirnya undang-undang yang mengatur tentang produk halal itu sendiri, yaitu Undang-Undang Nomor 33 tahun 2014 dan telah dibentuknya Badan Penyelenggara Jaminan Produk Halal (BPJPH) yang bertugas untuk menyelenggarakan jaminan produk halal di Indonesia, tetapi badan ini dinilai belum berjalan secara optimal. Hal ini disebabkan BPJPH saat ini dinilai belum siap untuk menerima dan melayani permohonan sertifikasi halal.

Seorang Ekonom dari lembaga Core Indonesia menyampaikan bahwa industri halal di Indonesia masih menemui kendala. Pertama, peluang bisnis industri halal belum didasari banyak pihak maupun regulator. Kedua, terbatasnya suplai bahan baku yang memenuhi kriteria halal. Hal ini terlihat dari pasokan bahan baku halal yang ada di Indonesia masih sekitar 37\% dari total kebutuhan. Padahal di sisi lain melimpahnya sumber daya alam di Indonesia jika dikelola dengan baik akan menghasilkan bahan baku yang memenuhi kriteria halal. Ketiga, masih terbatasnya pemahaman pada sejumlah produsen yang disertai dengan

\footnotetext{
${ }^{5}$ M. B. Milles dan M. A. Huberman, Qualitative Data Analysis (London: Sage Publication, 1984), 85.
} 
belum memadainya infrastruktur. Hal ini akhirnya mempersulit jaminan mata rantai produksi barang telah benar-benar halal. Keempat, perbedaan standarisasi dan sertifikasi produk halal. ${ }^{6}$

Selain itu, tantangan yang dihadapi dalam mengembangkan industri halal di Indonesia yakni kurang optimalnya bank syariah dalam menjalankan perannya. Kurang optimalnya bank syariah dalam menjalankan perannya ini setidaknya disebabkan tujuh hal. Pertama, minimnya sumber daya manusia yang tidak hanya dapat memahami aspek fikih namun juga dapat memahami aspek finansial. Padahal dari segi jumlah, Indonesia merupakan negara dengan penduduk muslim terbesar dunia yang tentunya ini bisa menjadi modal bagi bank syariah dalam menciptakan sumber daya yang berkualitas. Namun jumlah penduduk muslim terbesar dunia rupanya tidak menjamin tersedianya sumber daya insani yang berkualitas. Kedua, masih kurangnya edukasi bank syariah terhadap masyarakat "lapisan bawah" yang nota bene sebagai pemegang peranan penting pada sektor UMKM. Ketiga, kurang aktifnya bank syariah dalam pembiayaan. Hal ini bisa ditunjukkan dengan masih sulitnya proses pengurusan dan pengajuan pembiayaan di bank syariah. Keempat, adanya salah satu tindakan moral hazard dalam bentuk asimetri informasi antara bank syariah dengan nasabah. Kelima, masih maraknya penyelewengan yang dilakukan oleh beberapa oknum yang bekerja di bank syariah. Keenam, bank syariah sebagai mitra pelaku UMKM yang dinilai belum maksimal, sebab bank syariah hanya sebatas membantu dalam pemberian pembiayaan saja, tapi tidak turut serta membantu memajukan UMKM dalam meningkatkan pendapatannya. Ketujuh, masih sedikitnya jumlah bank syariah yang ada di Indonesia yang menyebabkan bank syariah belum menjangkau hingga ke pelosok-pelosok daerah. Bahkan di satu provinsi, bank syariah yang beroperasi tidak lebih dari lima kantor cabang.

\section{Sinergi Kelembagaan dalam Upaya Optimalisasi Peran Bank Syariah dalam Mengembangkan Industri Halal}

Bank Syariah sebagai lembaga keuangan yang menjadi salah satu tonggak perekonomian di Indonesia memiliki peluang yang sama besar dengan lembaga keuangan lainnya. Peran yang dapat dilakukan bank syariah cukup banyak dan sangat beragam. Namun untuk mengoptimalkan perannya, bank syariah sebaiknya melakukan sinergi kelembagaan dengan pihak-pihak yang berkepentingan dan memiliki visi yang sama dalam mengembangakan industri halal di Indonesia. Berikut sinergi kelembagaan yang dapat dilakukan bank syariah dalam upaya optimalisasi peran dalam mengembangkan indutri halal di Indonesia.

\section{Sinergi Kelembagaan dengan Pemerintah}

Upaya optimalisasi pertama yang harus dilakukan oleh bank syariah dalam mengembangkan industri halal adalah dengan melakukan sinergi kelembagaan dengan pemerintah. Bank syariah harus bisa bersinergi, berjalan bersama-sama, saling berdampingan dalam mengembangkan industri halal karena pemerintah selaku stakeholder yang sangat berpengaruh sekaligus pemegang kekuasaan dan pengambil kebijakan tertinggi.

\footnotetext{
${ }^{6}$ Akmad Akbar Susamto, “Core: 4 Tantangan Pengembangan Industri Halal”, medcom.id, 2017.
} 
Hal ini dinyatakan oleh Direktur LPPOM MUI Provinsi Gorontalo ${ }^{7}$ yang menyatakan bahwa bank syariah harus bersinergi dengan pemerintah, misalnya dalam bentuk pemberian subsidi kepada pelaku industri halal dan dalam hal memberikan bantuan atau subsidi dana untuk sertifikasi produk, sebab para pelaku industri halal, khususnya sektor makanan ini masih baru dan biasanya mereka kesulitan dalam membiayai administrasi untuk sertifikasi produk halal. Oleh karena itu, sinergi antara pemerintah dengan bank syariah dalam hal pemberian subsidi kepada pelaku industri halal khsususnya sektor makanan dan minuman menjadi penting agar pelaku industri halal ini bisa lebih dapat mengembangkan usahanya. Apalagi pemerintah sebagai pengambil kebijakan tertinggi tentunya memiliki kuasa yang lebih dalam hal pengembangan industri halal itu sendiri.

Adapun Langkah-langkah yang dapat dilakukan bank syariah dalam rangka sinergi kelembagaan dengan pemerintah adalah:

1. Identifikasi dan pemetaan wilayah sektor halal tourism

Bentuk sinergi kelembagaan bank syariah dengan pemerintah yang harus dilakukan pertama adalah secara bersama-sama melakukan identifikasi dan pemetaan wilayah sektor halal tourism. Identifikasi dan pemetaan wilayah ini dapat dilakukan dengan memanfaatkan kearifan lokal di masing-masing daerah. Indonesia yang kaya akan budaya, sumber daya dan didukung oleh jumlah modal manusianya tentunya sangat berpotensi dalam mengembangkan industri halal. Apalagi Indonesia adalah negara konsumtif terbesar di dunia. ${ }^{8}$

Identifikasi dan pemetaan wilayah sektor halal tourism ini tentunya mutlak dan harus dilakukan sebab wilayah Indonesia yang terdiri dari beragam budaya, adat istiadat, sumberdaya alam, produk unggulan daerah dan lain sebagainya. ${ }^{9}$ Bank syariah bisa berkolaborasi dengan pemerintah dalam hal misalnya memetakan wilayah mana yang sekiranya bisa dijadikan ikon, atau pusat wisata halal yang ada di Indonesia. Karena luasnya Indonesia, banyak wilayahnya, budayanya berbeda-beda, maka dari sekian banyak wilayah dan budaya, pasti ada kearifan lokal yang unggul di masing-masing wilayah atau daerah yang bisa dimanfaatkan sebagai wisata halal. Oleh karena itu pemerintah bisa melakukan pemetaan terhadap wilayah-wilayah mana saja yang bisa dijadikan wisata halal.

Wilayah Indonesia yang terdiri dari pulau-pulau hendaknya dimanfaatkan sebaik mungkin oleh bank syariah dan pemerintah dalam mengembangkan industri halal dengan cara melakukan identifikasi dan pemetaan wilayah dan sektor halal tourism. Identifikasi dan pemetaan wilayah ini tentunya selaras dengan tujuan pemerintah dalam mengembangkan industri halal di Indonesia. Identifikasi dan pemetaan wilayah sektor halal tourism ini bisa bekerjasama dengan kementrian pariwisata apalagi Kementerian Pariwisata kini telah melakukan kerjasama dengan Tim Percepatan dan Pengembangan Wisata Halal untuk memobilisasi industri, mengembangkan peraturan secara agresif untuk mempromosikan Indonesia sebagai tujuan halal yang ramah. Selain itu, bank syariah juga bisa melakukan kerjasama dengan Kementerian Perindustrian yang telah

\footnotetext{
${ }^{7}$ Astin Lukum, Wawancara, Gorontalo, 10 Juli 2018.

${ }^{8}$ Sudarto, "23 Industri Kecil di Lombok Raih Sertifikasi Halal”, Kompas.com, 2017.

${ }^{9}$ Riyan Naki, Wawancara, Bone Bolango, 28 Juni 2018.
} 
merencanakan untuk membentuk kawasan industri yang diharapkan dapat selesai sebelum tahun 2020. Hal tersebut karena seiring besarnya permintaan terhadap produk halal di dunia.

Identifikasi dan pemetaan wilayah sektor halal torism ini dapat dilakukan dengan memanfaatkan kearifan lokal di masing-masing daerah. Global Islamic Economy Report periode 2017-2018 menuliskan bahwa ekonomi Islam saat ini berada pada titik puncak pertumbuhan yang besar dan mendapat pengakuan yang luas setelah memperoleh daya tarik dan perhatian ketika umat Islam menekankan tentang nilai-nilai keagamanaan atau religiusitas dan nilai-nilai tradisional. Berdasarkan hal ini, tentu bank syariah bisa mengoptimalkan perannya mengembangkan industri halal di Indonesia. Identifikasi dan pemetaan wilayah sektor halal tourism dilakukan dengan mengidentifikasi peluang dan potensi apa yang bisa dikembangkan di daerah tersebut tanpa meninggalkan nilai-nilai religiusitas dan kearifan lokal yang ada di daerah tersebut. Contohnya Provinsi Gorontalo yang disebut sebagai kota Serambi Madinah ini memiliki falsafah "adat bersendikan syara, syara bersendikan kitabullah". Falsafah ini terus dipegang teguh oleh masyarakat Gorontalo. Dari falsafah ini, lahir kearifan lokal yang dapat dijadikan potensi wisata dan industri halal di Gorontalo. Misalnya, setiap malam ke-27 Ramadan sampai malam lebaran Idul Fitri di daerah ini melakukan trandisi tumbilotohe. Tumbilotohe atau biasa disebut dengan malam pasang lampu sudah menjadi tradisi di Provinsi Gorontalo dan tradisi tersebut sudah menjadi keunikan di Provinsi Gorontalo. Selanjutnya tradisi walima yang ada di Gorontalo. Tradisi walima ini biasanya dilakukan untuk memperingati maulid Nabi Muhammad. Pada tradisi ini, ada kue khas bernama kue kolombengi yang harus dihidangkan dan ditata rapi di sebuah tempat yang berbentuk perahu atau dalam bentuk lain. Selain itu di Gorontalo ada juga pasar yang diselenggarakan khusus dari hari ke-15 Ramadan sampai malam takbiran. Pasar ini disebut dengan Pasar Senggol.

Dengan memanfaatkan momen-momen kearifan lokal, maka industri halal yang ada di Indonesia dapat berkembang namun hal ini tentunya perlu dukungan dari bank syariah. Jadi tugas bank syariah saat ini adalah mendukung bahkan bisa melakukan kerjasama dengan beberapa kementerian dan lembaga, pemerintah pusat, bahkan pada tingkat terkecil, yakni pemerintah desa sebab desa memiliki peranan yang strategis dalam pengembangan desa wisata halal. Desa wisata halal dinilai menjadi bukti fleksibelnya syariah Islam pada ranah gaya hidup melalui intergrasi nilai halal yang baik dalam sektor pariwisata guna menunjang perekonomian daerah. ${ }^{10}$

Dengan dilakukannya identifikasi dan pemetaan wilayah sektor halal tourism akan mempermudah pemerintah dan bank syariah dalam melihat peluang dan potensi dalam mengembangkan industri halal sehingga dapat meningkatkan industri keuangan syariah yang pada akhirnya dapat menumbuhkan perekonomian di Indonesia.

Pemerintah Provinsi Gorontalo sebagai salah satu provinsi di Indonesia, mendukung dalam pengembangan industri halal. Industri halal di Gorontalo dapat berkembang dengan baik karena sudah menjadi keharusan sakaligus dapat meningkatkan pendapatan masyarakat serta meningkatkan pertumbuhan ekonomi. Pelaku industri halal

\footnotetext{
${ }^{10}$ Adinugraha, dkk, "Desa Wisata Halal: Konsep dan Implementasinya di Indonesia", Human Falah, Volume 5, Nomor 1 (2018), 72.
} 
bisa menerapkan konsep halal secara global, regional maupun lokal. Pemerintah Provinsi Gorontalo dalam mengembangkan industri halal hanya memfasilitasi dan membuat regulasi serta melakukan monitoring dan evaluasi. ${ }^{11}$

Semua pemerintah yang ada di masing-masing wilayah di Indonesia kiranya juga dapat memberikan dukungan moril maupun materil dalam pengembangan industri halal. Hal ini juga harus didukung oleh regulasi yang ada di masing-masing wilayah dengan tetap memperhatikan kearifan lokal, maupun budaya yang ada.

2. Dukungan penguatan regulasi, standarisasi, dan proses pengawasan terhadap produk halal

Diluncurkannya Undang-Undang Nomor 33 Tahun 2014 tentang Jaminan Produk Halal dan diresmikannya BPJPH yang bertugas dalam menyelenggarakan jaminan produk halal di Indonesia dinilai belum berjalan secara optimal. Sertifikasi halal yang digunakan saat ini hanya sertifikasi halal yang dikeluarkan oleh LPPOM MUI. Sejauh ini proses sertifikasi halal di Indonesia sudah berjalan. Namun, beberapa perusahaan yang belum melakukan proses verifikasi untuk mendapatkan sertifikasi halal. Sampai dengan 11 oktober 2017, jumlah sertifikasi halal yang telah dikeluarkan oleh LPPOM MUI sebanyak 7764 sertifikat halal dari 259984 produk dan dari 6055 perusahaan yang beroperasi di Indonesia. Hal ini menunjukkan semakin banyak perusahaan yang sadar akan pentingnya label halal dalam produk mereka. Meskipun demikian, masih banyak juga produk-produk ilegal dan tidak ada label halalnya. Padahal sertifikasi halal dan peran pemerintah dalam hal ini sangat mempengaruhi konsumtif wisatawan. ${ }^{12}$

Berdasarkan hasil pengawasan Badan POM sejak bulan Januari sampai dengan Oktober 2017, ditemukan 491.667 kotak kosmetik lokal dan 756.495 kotak kosmetik impor ilegal di wilayah Indonesia. Badan POM juga menemukan 11.457 kotak kosmetik lokal dan 5.900 kotak kosmetik impor mengandung bahan berbahaya dengan nilai mencapai lebih dari 20,5 miliar rupiah. Dengan demikian dapat dikatakan bahwa penyelenggaraan sertifikasi halal di Indonesia belum optimal. Padahal sertifikasi halal ini merupakan sebuah keharusan. Selain itu, sertifikasi halal merupakan upaya yang ditempuh dalam mengawasi produk halal. Salah satu hal yang menyebabkan masih banyaknya produk yang belum tersertifikasi halal adalah biaya akad sertifikasi. Untuk mendapatkan sertifikasi halal, biaya yang harus dikeluarkan sebesar 2.5 juta rupiah. Biaya tersebut merupakan biaya akad sertifikasi. Produk-produk yang belum memiliki sertifikasi halal biasanya terkendala oleh besarnya biaya akad sertifikasi. Pada perusahaan atau pengusaha yang sudah mapan biaya akad sertifikasi ini terbilang kecil, namun bagaimana dengan pelaku UMKM? Di sinilah diperlukan peran dari bank syariah. Bank syariah bisa saja melakukan kerjasama dengan LPPOM MUI dalam membiayai atau memberikan subsidi sebagian dari biaya akad sertifikasi, atau bank syariah bisa memfasilitasi pelaku UMKM maupun industri halal dalam mengurusi sertifikasi halal dari produk mereka. ${ }^{13}$ Sebenarnya dengan lahirnya Undang-Undang tentang Jaminan Produk Halal dan adanya lembaga Badan Penyelenggara Jaminan Produk Halal (BPJPH)

\footnotetext{
${ }^{11}$ Idris Rahim, Wawancara, Gorontalo, 4 November 2020.

${ }^{12}$ Menur Kusumaningtyas dan Sri Lestari, "Model Pengembangan Makanan dan Pariwisata Halal di Indonesia", Media Mahardika, Volume 19, Nomor 1 (2020), 58.

13 Astin Lukum, Wawancara, Gorontalo, 10 Juli 2018.
} 
tentu menjadi sebuah terobosan dan regulasi yang cukup dalam hal pengembangan industri halal di Indonesia. Namun hal tersebut perlu dibarengi juga dengan pengawasan secara berkelanjutan dan pembinaan terhadap pelaku industri halal tersebut. ${ }^{14}$

Dalam mengembangkan industri halal di Indonesia, bank syariah harus memiliki regulasi yang cukup kuat. Regulasi tersebut tentunya harus mendapat dukungan kelembagaan yang kuat dari pemerintah. Berkaca pada Malaysia di mana pemerintah Malaysia memberikan dukungan yang kuat dalam mengembangkan industri halal sehingga menjadikan Malaysia sebagai pusat utama untuk produk halal di kancah dunia. Salah satu dukungan yang diberikan oleh Pemerintah Malaysia adalah dengan menugaskan beberapa lembaga federasi untuk memainkan peran dalam mengembangkan industri halal. Salah satu lembaga yang ditugasi yakni Halal Development Corporation (HDC). HDC ini merupakan lembaga yang didirikan untuk memposisikan Malaysia sebagai pusat halal global dan untuk mempercepat pengembangan industri halal di seluruh dunia dengan memfokuskan pada pengembangan standar halal dan pengembangan kapasitas produk dan layanan halal.

Bukti lanjut dari dukungan Pemerintah Malaysia dalam mengembangkan industri halal yakni dengan menyelenggarakan Halal Malaysia Week. Acara tahunan ini merupakan penggabungan tiga acara, yaitu Malaysia International Halal Showcase (MIHAS), World Halal Research Summit (WHR) dan World Halal Forum (WHF) yang memiliki tujuan untuk memperluas pertumbuhan industri halal secara global melalui perdagangan, pameran, forum diskusi maupun penelitian. Selain itu, Pemerintah Malaysia telah melakukan langkah-langkah signifikan dalam mendukung pengembangan pasar halal dengan mempromosikan produk dan layanana halal. Malaysia menjadikan dirinya sebagai pusat untuk sertifikasi produk halal. Lembaga yang menangani sertifikasi halal di bawah naungan Jabatan Kemajuan Islam Malaysia (JAKIM) dan merupakan lembaga yang berwenang dalam mengeluarkan sertifikasi halal di Malaysia. Proses pemberian sertifikasi halal di negara ini tidak jauh berbeda dengan pemberian sertifikasi halal oleh LPPOM MUI. Pemberian sertifikasi di Malaysia yakni dengan memberikan izin perusahaan dalam penggunaan logo halal pada kemasan produknya. Selain itu juga JAKIM bertanggung jawab dalam memantau dan menegakkan integritas sertifikasi halal. Hal ini dilakukan dengan melibatkan serta memastikan persyaratan sertifikasi halal terpenuhi di seluruh proses produksi termasuk pada penanganan produksi, pengemasan, transportasi maupun penyimpanan.

Pemerintah Indonesia sebenarnya sudah berupaya dalam mengembangkan industri halal. Bukti nyata Pemerintah Indonesia ini diwujudkan dengan dibentuknya BPJPH, lahirnya Undang-Undang Nomor 33 tahun 2014 tentang Jaminan Produk Halal, adanya Lembaga Penyelenggara Produk Halal (LPPOM) oleh Majelis Ulama Indonesia (MUI). Upaya pemerintah dalam mengembangkan industri syariah ini harus mendapatkan dukungan dari bank syariah. Bank syariah dan pemerintah harus bersinergi dalam mengembangkan industri halal melalui penguatan regulasi, standarisasi dan pengawasan terhadap produk halal. Sebab isu halal ini menjadi sebuah peluang yang sangat besar

\footnotetext{
14 Ibid.
} 
dalam meningkatkan bahkan dapat memperbaiki perekonomian ${ }^{15}$ nasional maupun daerah.

\section{Sinergi Bank Syariah dengan Pelaku Industri Halal}

Pelaku industri halal merupakan salah satu pihak yang cukup berpengaruh dalam mengembangkan industri halal di Indonesia. Dalam hal ini, bank syariah harus bersinergi dengan pelaku industri halal itu sendiri. Bentuk sinergi antara bank syariah dengan pelaku industri halal yakni:

1. Identifikasi dan pengembangan model industri

Bank syariah dalam mengembangkan industri halal yakni dengan melakukan identifikasi dan pengembangan model industri. Strategi pengembangan model industri dilakukan dengan mengadopsi konsep kluster industri. Kluster industri merupakan konsentrasi geografis dari perusahaan industri dan institusi yang saling berhubungan. Hal ini karena adanya kesamaan produk serta saling melengkapi. ${ }^{16}$ Pembagian kluster industri berdasarkan fase pertumbuhannya dilakukan dengan mempertimbangkan beberapa dimensi, yaitu ukuran kluster, pasar atau kinerja dan kolaborasi antara stakeholder. ${ }^{17}$

Pelaku industri halal juga berharap kepada pemerintah maupun lembaga terkait lainnya dalam hal pengidentifikasian dan pengembangan model indutri halal itu sendiri. Dalam pengembangan kluster industri biasanya akan ada tantangan dalam hal mengelola kerjasama dan berbagai pengetahuan di antara anggota kluster. ${ }^{18}$ Namun tantangan tersebut bisa diselesaikan asalkan pihak-pihak yang terkait dapat bersinergi dengan baik.

2. Dukungan penguatan dan penyediaan outlet dan akses pasar

Bank syariah dalam mengembangkan industri halal di Indonesia harus memberikan dukungan sebagai penguatan kepada industri halal dengan cara menyediakan outlet dan akses pasar. Akses pasar menjadi salah satu hal penting dalam mengembangkan industri halal. Namun dalam penyediaan akses pasar ini biasanya pelaku industri seperti UMKM masih memiliki beberapa kendala, seperti pelaku UMKM tersebut belum memiliki legalitas atas usaha yang dimilikinya. Selain itu, biaya operasional untuk sampai ke pelanggan dirasa cukup besar oleh para pelaku industri yang industrinya masih kecil seperti UMKM. Sebelum menyediakan outlet dan akses pasar, bank syariah terlebih dahulu melakukan penguatan dalam bentuk training atau sosialisasi tentang akses pasar, sehingga pelaku industri memahami betul arti penting akses pasar dan kualitas produk yang nantinya dapat meningkatkan hasil produksi. Dalam training ini nantinya bank syariah juga akan menunjukkan pada pelaku industri agar mereka mengetahui tentang bagaimana prosedur, cara bernegosiasi harga maupun barang, bagamana situasi dan kondisi di pasar, sehingga pelaku industri dapat menjual produknya tepat sasaran. Setelah

\footnotetext{
15 Sulistyo Prabowo dan Azmawani Abd Rahman, "Sertifikasi Halal Sektor Industri Pengolahan Hasil Pertanian", Forum Penelitian Agroekonomi, Volume 34, Nomor 1 (2016), 114.

16 Porter, The Competitive Advantage of Nations (New York: t.p., 1990), 136. Lihat juga Mulyadiana, dkk, "Pengembangan Model Penilaian Klaster (Studi Kasus: Klaster Industri Kota Surakarta)", Seminar dan Konferensi Nasional IDEC, 2017.

17 Faqiatul Mariya Waharini dan Anissa Hakim Purwantini, "Model Pengembangan Industri Halal Food di Indonesia", Jurnal Muqtasid, Volume 9, Nomor 1 (2018), 7.

${ }^{18}$ Dedy Sugiarto, dkk, "Pemilihan Strategi Pengembangan Klaster Industri dan Strategi Manajemen Pengetahuan pada Klaster Industri Barang Celup Latex”, Jurnal Teknik Industri, Volume 20, Nomor 2 (2010), 94.
} 
memberikan dukungan penguatan kepada pelaku industri, selanjutnya bank syariah dapat menyediakan outlet dan akses pasar kepada pelaku industri. ${ }^{19}$

Pentingnya penyediaan outlet dan akses pasar ini tentunya membutuhkan peran dan dukungan juga dari bank syariah, pemerintah baik di tingkat pusat, wilayah maupun daerah. Penyediaan outlet dan akses pasar dapat dilakukan dengan empat cara. Pertama, meningkatkan networking baru melalui pameran, baik lokal maupun secara nasional. Jaringan pemasaran baru ini bisa melalui festival keuangan syariah, pameran keuangan syariah, festival kuliner maupun kegiatan lain yang memiliki potensi dalam penyediaan akses pasar. Kedua, pengembangan kemitraan. Dalam hal ini bank syariah bermitra dengan pemerintah bahkan bila memungkinkan bank syariah melakukan kerjasama dengan beberapa lembaga yang dapat mendukung penyediaan akses pasar. Ketiga, memberikan subsidi keuangan kepada pelaku industri dalam hal perizinan ekspor yang menjadi salah satu kendala dalam mengakses pasar internasional. Karena dalam pengurusan perizinan ekspor membutuhkan biaya yang cukup besar ditambah dengan biaya pengiriman yang tidak kalah besar juga. Keempat, mempertemukan pelaku industri halal dengan penyedia bahan baku halal. Salah satu yang menjadi kendala pelaku industri halal yakni masih kurangnya bahan baku yang memenuhi kriteria halal yang dapat diolah menjadi produk. Meskipun melimpahnya Indonesia daya alam, untuk memperoleh bahan baku pembuatan produk, Indonesia harus mengimpor dari luar negeri. Oleh sebab itu bank syariah diharapkan dapat mengidentifikasi serta mempertemukan antara pelaku industri halal dengan pemilik bahan baku. Dengan melakukan empat cara tersebut, diharapkan bank syariah dapat melakukan optimalisasi perannya dalam mengembangkan industri halal.

3. Pemberian dana pembiayaan

Seiring perhatian pemerintah dalam mengembangkan industri halal, bank syariah tidak boleh kalah dalam mengoptimalisasikan perannya dalam mengembangkan industri halal. Peran yang dapat dilakukan bank syariah tersebut adalah dengan memberikan pembiayaan dalam bentuk modal kepada pelaku industri halal. Seperti yang kita ketahui bersama bahwa sistem bagi hasil merupakan sistem yang diterapkan bank syariah dalam memberikan pembiayaan dan sistem tersebut merupakan sistem alternatif yang cukup baik untuk digunakan. Namun hal mendasar yang harus kita pahami dan kita pastikan bersama bahwa apakah pembiayaan yang disalurkan bank syariah memang murni dan terbebas dari sistem riba. Karena masih banyak anggapan masyarakat yang menyamakan sistem bagi hasil di bank syariah sama dengan sistem bunga yang ada di bank konvensional. Mereka menganggap bahwa label syariah pada bank syariah belum tentu menjamin bahwa bank syariah tersebut bebas riba. Hal ini disebabkan oleh bank syariah yang masih menjadikan sistem bunga sebagai brenchmark dalam penetapan sistem bagi hasil. Bahkan dalam beberapa menyebutkan bahwa bank syariah sama saja dengan bank konvensioal hanya berbeda pada pakaian dan jenggotnya. ${ }^{20}$

\footnotetext{
${ }^{19}$ Suryanti, Wawancara, Gorontalo, 10 Juli 2018; Sri Endang, Wawancara, Gorontalo, 2 November 2019.

${ }^{20}$ Rania Kamla, "Critical Insights into Contemporary Islamic Accounting", Critical Perspectives on Accounting, Volume 20, Nomor 4 (2009), 927.
} 
Selain memastikan penyaluran pembiayaan yang murni dan bebas riba, bank syariah juga harus memperhatikan prosedur pada saat pelaku industri mengajukan dana pembiayaan di bank syariah. Pelaku industri halal sangat menyadari bahwa selain modal yang dimiliki oleh pelaku industri tersebut, mereka masih membutuhkan tambahan modal dari pihak kedua, yakni bank syariah. Namun terkadang pada saat pelaku industri mengajukan pembiayaan kepada bank syariah ada kesan yang timbul dari pelaku industri yang menyatakan prosesnya ribet. Harapan ke depan, bank syariah lebih memperhatikan lagi terkait prosedur dan layanan pembiayaan kepada pelaku industri halal.

Bank syariah dan pelaku industri halal pada dasarnya memiliki sikap ketergantungan, saling menguntungkan dan membutuhkan. Bank syariah mencari aset islami yang memang murni bebas dari sifat keharaman untuk tetap melangsungkan pertumbuhan dan kehidupan di bank syariah, di sisi lain juga pelaku industri halal membutuhkan modal untuk mengembangkan industri halalnya. Karena sebagian besar pelaku industri halal adalah perusahaan berskala kecil dan menengah. Pelaku industri yang seperti ini tentunya belum dapat mengambil manfaat dari pasar modal yang umumnya menguntungkan perusahaan skala besar. Oleh karena itu, bank syariah diharapkan lebih mengoptimalkan perannya dalam mengembangkan industri halal. Peran lain yang dapat dijalankan bank syariah adalah dengan memprogramkan lahirnya seribu pengusaha atau pelaku industri halal baru di setiap provinsi dan setiap tahun. Program ini tentunya membutuhkan modal dan biaya yang cukup besar, untuk itu bank syariah dapat bekerjasama dengan Kementrian Perindustrian, Kementrian Pariwisata dan lembagalembaga lainnya yang dapat mendukung pembiayaan, khususnya untuk mengembangkan industri halal di Indonesia.

Bank syariah memainkan peran penting dalam mengembangkan UMKM. ${ }^{21}$ Peran yang dimainkan bank syariah seharusnya memberikan produk-produk pembiayaan yang sesuai dengan kebutuhan yang sifatnya kompetitif dan mudah diakses oleh pelaku industri halal, contohnya yang bergerak pada sektor makanan halal. Karena pada umumnya industri halal berkembang dalam tiga dimensi dan bank syariah diharapkan dapat memainkan peran untuk memaksimalkan ketiga dimensi tersebut. Ketiga dimensi tersebut adalah pelaku industri diberikan kesempatan yang lebih besar agar dapat membangun dan mengembangkan produk-produk halal; industri halal dipromosikan sehingga dapat membangun kesadaran pentingnya penggunaan produk jasa halal; gaya hidup halal harus lebih dikembangkan. Namun berkenaan dengan pemberian dana pembiayaan oleh bank syariah kepada pelaku industri halal ini belum optimal karena mungkin di beberapa wilayah, bank syariah tidak menyediakan produk pembiayaan bagi pelaku usaha atau industri halal. ${ }^{22}$

Pemberian dana pembiayaan bagi pelaku industri halal ini harus terealisasi karena pelaku industri tersebut dalam mengembangkan usahanya membutuhkan modal dari pihak ketiga, dalam hal ini lembaga pembiayaan termasuk bank syariah yang harus

${ }^{21}$ Gillani, dkk, "Role of Islamic Financial Institutions in Promotion of Pakistan Halal Food Industri", Islamic Banking and Finance Review, Volume 3, Nomor 1 (2016), 37.

${ }^{22}$ Tantri, Wawancara, Gorontalo, 12 Juli 2019; Iman Koniyo, Wawancara, Gorontalo, 5 November 2020. 
memfasilitasi keinginan para pelaku usaha untuk mendapatkan modal dari lembaga yang sesuai dengan prinsip syariah. ${ }^{23}$

Berdasarkan pada hal ini tentunya dibutuhkan peran yang lebih kepada bank syariah dalam hal pemberian dana pembiayaan kepada pelaku industri halal. Sebab untuk memastikan kehalalan dari sebuah produk, dimulai dari perolehan modal sebagai dana untuk membiayai industri halal ataupun usaha harus sesuai dengan syariah. Namun nyatanya, pelaku industri halal sebagian besar memperoleh dana pembiayaan tersebut berasal dari lembaga konvensional yang nota bene identik dengan riba. Hal ini disebabkan karena di beberapa wilayah, lembaga syariah yang diharapkan dapat memberikan layanan atau produk dana pembiayaan kepada pelaku industri halal namun nyatanya tida menyediakan layanan atau produk tersebut kepada pelaku industri halal.

4. Edukasi dan pendampingan

Upaya sinergitas yang dapat dilakukan bank syariah dalam mengoptimalkan perannya dalam mengembangkan industri halal adalah dengan melakukan edukasi dan pendampingan. Edukasi ini disosialisasikan kepada seluruh lapisan masyarakat baik yang bergerak dalam bidang industri, maupun masyarakat yang belum memiliki usaha atau sebagai konsumen. Bentuk edukasi yang dapat dilakukan oleh bank syariah misalnya tentang workshop atau seminar tentang pentingnya mengkonsumsi makanan halal, bahaya makanan haram, atau edukasi kepada pelaku industri seperti pentingnya menggunakan bahan-bahan halal, pentingnya akses pasar, pentingnya service excellent kepada konsumen, edukasi tentang penggunaan modal yang diberikan oleh bank syariah kepada pelaku industri, edukasi tentang produk-produk maupun sistem bagi hasil di bank syariah, edukasi tentang pentingnya teknologi dalam pemasaran atau edukasi lainnya yang dapat mengembangakan industri halal di Indonesia. ${ }^{24}$

Selain edukasi, hal yang perlu dilakukan bank syariah adalah melakukan pendampingan kepada pelaku industri halal. Pendampingan ini dilakukan baik itu terkait dengan penggunaan dana pembiayaan yang telah diberikan oleh bank syariah, pendampingan terhadap pencatatan maupun pembukuan pembiayaan yang telah diberikan kepada pelaku industri atau melakukan pendampingan terhadap pengembangan industi halal itu sendiri, mulai dari proses produksi, promosi, pemasaran sampai pada proses pelaporan dan evaluasi. Edukasi dan pendampingan oleh bank syariah ini merupakan hal yang cukup penting. Hal ini disebabkan pertama, masih minimnya pemahaman masyarakat tentang pentingnya mengkonsumsi makanan halal. Paradigma yang selama ini berkembang di masyarakat adalah setiap barang yang diproduksi oleh orang yang beragama Islam itu sudah dipastikan kehalalannya. Padahal yang dapat memastikan kehalalan makanan di Indonesia adalah LPPOM MUI bahkan pemerintah telah membentuk BPJPH. Kedua, banyak pelaku industri yang belum memahami mekanisme dan prosedur pembiayaan di bank syariah, terutama pada saat bank syariah tersebut telah menyalurkan dana pembiayaan. Banyak tindakan moral hazard yang terjadi pada proses ini. Moral hazard yang bisa saja terjadi pada proses ini adalah side streaming. Side

\footnotetext{
${ }^{23}$ Lia Octavia, Wawancara, Gorontalo, 2 November 2019.

${ }^{24}$ Ibid.
} 
streaming merupakan penggunaan dana oleh nasabah tidak sesuai dengan kontrak yang telah disepakati. ${ }^{25}$

\section{Sinergi Bank Syariah dengan Lembaga Pendidikan Melalui Inklusi Kesadaran Industri Halal di Lembaga Pendidikan}

Lembaga pendidikan merupakan salah satu lembaga yang dapat mempengaruhi gaya hidup, lingkungan sosial, politik maupun ekonomi termasuk dalam hal industri halal. Adanya sinergitas antara bank syariah dengan lembaga pendidikan tentunya dapat mempercepat pertumbuhan dan perkembangan industri halal. Mengingat kontribusi industri halal sangat potensial dalam memperbaiki perekonomian di Indonesia namun masih dibarengi dengan masih minimnya masyarakat mengkonsumsi makanan atau menggunakan produk yang berlabel halal. Di sisi lain, banyaknya lembaga pendidikan di Indonesia yang dibarengi dengan banyaknya jumlah pendidik dan anak didik yang tentunya dapat mempengaruhi perkembangan industri halal di Indonesia. Bentuk sinergi yang dapat dilakukan bank syariah dengan lembaga pendidikan dalam mengembangkan industri halal di Indonesia yakni melalui inklusi kesadaran industri halal di lembaga pendidikan.

Inklusi kesadaran industri halal di lembaga pendidikan harus dilaksanakan. Sebab melalui jalur pendidikan, maka para pendidik maupun mahasiswa mampu mensosialisasikan betapa pentingnya akan konsep halal dan haram, makanan dan minuman apa saja yang boleh dikonsumsi serta produk-produk apa saja yang boleh digunakan. Selain itu, bank syariah bisa memberikan saran dan masukan dalam proses penyusunan kurikulum. ${ }^{26}$

Inklusi kesadaran industri halal di lembaga pendidikan merupakan hal yang harus dilakukan oleh bank syariah dalam mengembangkan industri halal melalui jalur lembaga pendidikan. Industri kesadaran industri halal ini merupakan upaya bersama yang dilakukan oleh bank syariah dengan Kemendikbud dan Kemenristek Dikti selaku pihak yang membidangi pendidikan untuk menanamkan kesadaran pentingnya industri halal kepada akademisi melalui integrasi materi kesadaran industri halal dalam pendidikan.

Pada APBN 2019, postur anggaran untuk pendidikan naik dari 444,1 triliun rupiah menjadi 492,5 triliun rupiah. Anggaran ini terdiri atas anggaran pendidikan melalui belanja Pemerintah Pusat sebesar 163,1 triliun rupiah, anggaran pendidikan melalui transfer ke daerah sebesar 308,4 triliun rupiah, dan anggaran pendidikan melalui pembiayaan sebesar 21 triliun rupiah. Bersarnya postur anggaran untuk lembaga pendidikan tentunya ini menjadi potensi dalam mengembangkan industri halal. Bank syariah dapat membuat roadmap edukasi dalam mengembangkan industri halal melaui inklusi kesadaran industri halal di lembaga pendidikan.

Tabel 1.1. Roadmap Edukasi

\begin{tabular}{|l|l|}
\hline \multicolumn{1}{|c|}{ Periode } & \multicolumn{1}{c|}{ Keterangan } \\
\hline $\begin{array}{l}\text { Masa Edukasi } \\
2020-2022\end{array}$ & $\begin{array}{l}\text { Kesadaran pentingnya industri halal disosialisasikan dan dibelajarkan kepada } \\
\text { seluruh elemen perguruan tinggi maupun sekolah }\end{array}$ \\
\hline $\begin{array}{l}\text { Masa Kesadaran } \\
\text { 2023-2025 }\end{array}$ & $\begin{array}{l}\text { Pendidikan kesadaran industri halal terus dilakukan } \\
\text { Inklusi kesadaran industri halal dalam bentuk produk hukum }\end{array}$ \\
\hline
\end{tabular}

${ }^{25}$ Muhammad Syafi'i Antonio, Bank Syariah dari Teori ke Praktik (Jakarta: Gema Insani Press, 2001$), 93$.

${ }^{26}$ Ismail Y. Puhi, Wawancara, Gorontalo, 30 Oktober 2019. 


\begin{tabular}{|l|ll|}
\hline $\begin{array}{l}\text { Masa Kejayaan } \\
\text { Industri Halal } \\
\text { 2026-seterusnya }\end{array}$ & $\begin{array}{l}\text { Pendidikan kesadaran akan industri halal terus berlanjut } \\
\text { Aspek industri halal saling terhubung antar lembaga pemerintah pusat, } \\
\text { daerah maupun swasta }\end{array}$ \\
& $\begin{array}{l}\text { Warga negara akan merasa malu jika belum menggunakan produk berlabel } \\
\text { halal dan pelaku industri halal malu jika produknya belum berlabelkan atau } \\
\text { tersertifikasi halal }\end{array}$ \\
\hline
\end{tabular}

Berdasarkan pada roadmap edukasi di atas, maka program yang dapat dijalankan guna mendukung inklusi kesadaran industri halal di perguruan tinggi adalah bank syariah melakukan MoU dengan kementrian terkait, seperti Kementrian Keuangan, Kemenristekdikti, Kementrian Agama, Kementrian Perindustrian, Kementrian Pariwisata dan sebagainya; penerbitan buku materi kesadaran industri halal yang memuat tentang pentingnya kehalalan dalam kehidupan; materi kampanye melalui logo dan lagu; kebijakan dan regulasi inklusi kesadaran industri halal; MoU bank syariah dengan perguruan tinggi; rapat koordinasi; sharing dan edukasi dosen maupun guru; kurikulum inklusi kesadaran industri halal; monitoring dan evaluasi; launching e-riset industri halal; Eduhalal Award; duta ekonomi syariah atau duta industri halal.

\section{Kesimpulan}

Optimalisasi peran bank syariah dalam mengembangkan industri halal di Indonesia harus mendapat dukungan penuh baik moril maupun materil dari pemerintah pusat maupun pemerintah daerah serta stakeholders yang berkepentingan. Peluang maupun tantangan dalam mengembangkan industri halal akan semakin besar. Peluang dan tantangan tersebut akan mempengaruhi perkembangan dan pertumbuhan industri halal. Oleh sebab itu, sinergi kelembagaan antara bank syariah dengan pemerintah maupun kementerian dan lembaga terkait sangat dibutuhkan. Hal yang dapat dilakukan bank syariah dalam mengoptimalisasikan perannya dalam mengembangkan industri halal di Indonesia adalah melalui sinergi kelembagaan. Sinergi kelembagaan yang dapat dilakukan bank syariah adalah pertama, sinergi kelembagaan dengan pemerintah. Adapun bentuk sinergi kelembagaan yang dilakukan bank syariah dengan pemerintah adalah identifikasi dan pemetaan wilayah sektor halal tourism; dukungan penguatan regulasi, standarisasi, dan proses pengawasan terhadap produk halal. Kedua, sinergi kelembagaan bank syariah dengan pelaku industri halal. Bentuk sinergi kelembagaan dengan bank syariah dengan industri halal dapat dilakukan dengan identifikasi dan pengembangan model industri; dukungan penguatan dan penyediaan outlet dan akses pasar; pemberian dana pembiayaan; edukasi dan pendampingan. Ketiga, sinergi bank syariah dengan lembaga pendidikan melalui inklusi kesadaran industri halal di lembaga pendidikan.

\section{Daftar Rujukan}

Adinugraha, dkk. "Desa Wisata Halal: Konsep dan Implementasinya di Indonesia", Human Falah, Volume 5, Nomor 1 (2018).

Antonio, Muhammad Syafi'i. Bank Syariah dari Teori ke Praktik. Jakarta: Gema Insani Press, 2001.

Endang, Sri. Wawancara. Gorontalo, 2 November 2019.

Fasih. "Inclusiv Growth in India through Islamic Banking", Procedia Social-Behavioral 
Science, Volume 37, Nomor 1 (2012).

Gillani, dkk. "Role of Islamic Financial Institutions in Promotion of Pakistan Halal Food Industri”, Islamic Banking and Finance Review, Volume 3, Nomor 1 (2016).

Kamla, Rania. "Critical Insights into Contemporary Islamic Accounting", Critical Perspectives on Accounting, Volume 20, Nomor 4 (2009).

Koniyo, Iman. Wawancara. Gorontalo, 5 November 2020.

Kornitasari, dkk. "Desain Kelembagaan dalam Membangun Kepercayaan Diri Perbankan Syariah: Peran, Fungsi dan Potensi Kinerja Sektor Riil di Indonesia”, Kumpulan Hasil Riset Terbaik FREKS, 2015.

Kusumaningtyas, Menur dan Sri Lestari. "Model Pengembangan Makanan dan Pariwisata Halal di Indonesia", Media Mahardika, Volume 19, Nomor 1 (2020).

Lukum, Astin. Wawancara. Gorontalo, 10 Juli 2018.

Milles, M. B. dan M. A. Huberman. Qualitative Data Analysis. London: Sage Publication, 1984.

Mulyadiana, dkk. "Pengembangan Model Penilaian Klaster (Studi Kasus: Klaster Industri Kota Surakarta)", Seminar dan Konferensi Nasional IDEC, 2017.

Naki, Riyan. Wawancara. Bone Bolango, 28 Juni 2018.

Octavia, Lia. Wawancara. Gorontalo, 2 November 2019.

OJK, “Aset Bank Syariah Tumbuh 20,65\% Per Februari”, Kontan, Februari 2018.

Porter. The Competitive Advantage of Nations. New York: t.p., 1990.

Prabowo, Sulistyo dan Azmawani Abd Rahman. "Sertifikasi Halal Sektor Industri Pengolahan Hasil Pertanian”, Forum Penelitian Agroekonomi, Volume 34, Nomor 1 (2016).

Puhi, Ismail Y. Wawancara. Gorontalo, 30 Oktober 2019.

Rahim, Idris. Wawancara. Gorontalo, 4 November 2020.

Sudarto. "23 Industri Kecil di Lombok Raih Sertifikasi Halal”, Kompas.com, 2017.

Sugiarto, Dedy, dkk. "Pemilihan Strategi Pengembangan Klaster Industri dan Strategi Manajemen Pengetahuan pada Klaster Industri Barang Celup Latex", Jurnal Teknik Industri, Volume 20, Nomor 2 (2010).

Suryanti. Wawancara. Gorontalo, 10 Juli 2018.

Susamto, Akmad Akbar. "Core: 4 Tantangan Pengembangan Industri Halal", medcom.id, 2017.

Tantri. Wawancara. Gorontalo, 12 Juli 2019.

Waharini, Faqiatul Mariya dan Anissa Hakim Purwantini. "Model Pengembangan Industri Halal Food di Indonesia”, Jurnal Muqtasid, Volume 9, Nomor 1 (2018). 